\title{
Multiple regression analysis predicts the dynamic of chondrocytes stimulated by magnetic and electric fields
}

\author{
JUAN JAIRO VACA-GONZÁLEZ ${ }^{1,2}$, JUAN FELIPE ESCOBAR ${ }^{2,3}$, \\ DIEGO ALEXANDER GARZÓN-ALVARADO ${ }^{2,4}$ \\ ${ }^{1}$ School of Health and Sports Sciences, Master Program in Epidemiology, \\ Fundación Universitaria del Área Andina, Bogotá, Colombia. \\ ${ }^{2}$ Biomimetics Laboratory, Instituto de Biotecnología, Universidad Nacional de Colombia, Bogotá, Colombia. \\ ${ }^{3}$ Research group in Design, Analysis and Development of Engineering Systems - GIDAD, \\ Fundación Universitaria Los Libertadores, Bogotá, Colombia. \\ ${ }^{4}$ Numerical Methods and Modeling Research Group (GNUM), Universidad Nacional de Colombia, Bogotá, Colombia.
}

\begin{abstract}
Purpose: The aim of this study was to implement a multiple regression analysis to find mathematical models that estimate the proliferative rate and the molecular synthesis of chondrocytes when these cells are stimulated either by magnetic or electric fields. Methods: Data derived from previous studies performed in our laboratory were used for statistical analyses, which consisted of applying magnetic fields ( 1 and $2 \mathrm{mT})$ and electric fields $(4$ and $8 \mathrm{mV} / \mathrm{cm})$ to chondrocytes. Data from cell proliferation and glycosaminoglycan expression were used to adjust and to validate each mathematical model. Results: The root square model efficiently predicted the chondrocyte dynamics, evidencing determination coefficients of $R^{2}=92.04$ for proliferation and $R^{2}=70.95$ for glycosaminoglycans when magnetic fields were applied, and $R^{2}=88.19$ for proliferation and $R^{2}=74.79$ for glycosaminoglycans when electric fields were applied. Conclusions: The reduced, interactive, quadratic and combined models exhibited lower $R^{2}$ values, nevertheless, they were useful to predict proliferation and glycosaminoglycan synthesis, as the right-skewed distribution, determined by the $F$ pa-

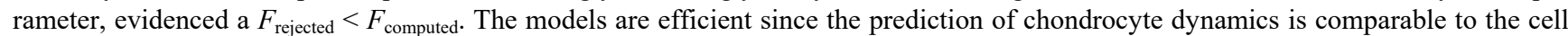
growth and to the molecular synthesis observed experimentally. This novel formulation may be dynamic because the variables that fit the models may be modified to improve in vitro procedures focused on cartilage recovery.
\end{abstract}

Key words: multiple regression analysis, electric fields, magnetic fields, chondrocyte dynamics

\section{Introduction}

Biophysical stimuli such as magnetic fields (MFs) and electric fields (EFs) have been implemented to stimulate chondrocyte dynamics. On one hand, MFs have been applied to in vitro cultures to preserve chondrocytes morphology [22], increase DNA synthesis [29], and enhance proliferation and glycosaminoglycan (GAGs) synthesis [34]. MFs have been applied to cartilage explants either to improve synthesis of proteoglycans and stimulate anabolic activities [30], [31] or to counteract catabolic activities and enhance osteo- arthritis [37]. Application of MFs has been investigated in chondrocytes cultured in scaffolds. For example, osteoarthritic chondrocytes encapsulated within alginate structures expressed more proteoglycans when MFs were applied [15]. In studies by Schmidt-Rohlfing et al. [42], and Nicolin et al. [35], it was possible to observe that MFs applied to articular chondrocytes cultured in collagen membranes increased cell proliferation, synthesis of collagen type II and proteoglycans in the pericellular region. MFs have been applied in vivo in the recovery of knee osteoarthritis. For instance, MFs preserved the articular cartilage morphology [10], [13], [14], retarded the development of lesions [10],

\footnotetext{
* Corresponding author: Juan Jairo Vaca-González, Biomimetics Laboratory, Instituto de Biotecnología, Universidad Nacional de Colombia, Bogotá, Colombia. Phone: 571 7421934, e-mail: jvaca8@areandina.edu.co,jjvacag@unal.edu.co

Received: March 29th, 2021

Accepted for publication: July 22nd, 2021
} 
and improved joint motion, pain and tenderness [34], [39], [46], [47]. On the other hand, EFs have been applied in vitro to increase chondrocyte proliferation and GAGs synthesis [2], [6], [7], [40]. Wang et al. [52], elucidated that EFs increased aggrecan and collagen type II synthesis. EFs have been applied to cartilage explants and scaffolds. For instance, cartilage explants stimulated with EFs experienced an increase in proteoglycans (34\%) and collagen type II (71\%) after 14 days of stimulation [8]. Osteoarthritic human cartilage explants were stimulated with EFs. Results showed 1.4 and 1.5-fold increase in proteoglycans and collagen type II, respectively [9]. EFs have been applied to scaffolds used for cartilage repair, however, the reports in literature are limited and the results have been contradictory. For instance, chondrocytes seeded into agarose gels and electrically stimulated increased in cell density and GAGs synthesis [45]. In contrast, Akanji et al. [1], investigated the effects of direct current on cell proliferation and matrix synthesis, using a 3D chondrocyteagarose scaffold. Their results demonstrated that EFs have no influence over protein synthesis, cell proliferation and mRNA expression.

Based on the above, MFs and EFs modulate chondrocyte dynamics favoring cell proliferation, chondrocyte morphology and molecular synthesis. However, there are relevant stimulation parameters to find the best combination to stimulate chondrocytes [48]. These parameters include intensities of MFs and EFs to stimulate chondrocytes, stimulation time per day, and the days that the cells need to be under stimulation. By controlling and varying these parameters, it is going to be possible to estimate either the best proliferation rate or the desired increase in molecular synthesis. For this reason, it is necessary to use alternative methods that make it possible not only to mimic cell biology experiments, but also to predict cell dynamics when the variables previously mentioned vary. Accordingly, several mathematical models were implemented to simulate cell dynamics, such as exponential logistic growth equations [20], [24], [25], [53], growth [3], [43], linear regression [38], monod [5], [11], [44] and agentbased models [18], [19], [28]; and a combination of models [36], [41], [54]. Nevertheless, there is no model that simulates cell response when external biophysical stimuli are applied to cell cultures. Therefore, in this study, a multiple regression analysis was implemented to find the equations that estimate the proliferative rate and the molecular synthesis of GAGs when chondrocytes are stimulated by MFs and EFs. The implementation of a combined experimental and mathematical approach allows to predict the MFs and EFs that stimulate in vitro alternative chondrocytes, reducing the number of experimental assays and providing a costeffective in cartilage tissue engineering. Additionally, the standardization of a well-stablished protocol allows for the analysis of different MF and EF intensities and stimulation times to better understand the impact of biophysical stimulation on cell dynamics during the process of articular cartilage maintenance.

\section{Materials and methods}

\subsection{Data acquisition for statistical analysis}

Data derived from previous studies carried out in our laboratory were used in this study. Regarding the magnetic stimulation, data of cell proliferation and GAGs synthesis were acquired from the study [12]. Here, chondrocytes were stimulated with MFs of 1 and $2 \mathrm{mT}$ at $60 \mathrm{~Hz}$. These magnitudes were applied to chondrocytes for 1, 3 and $5 \mathrm{~h}$ every $6 \mathrm{~h}$ for 8 days. Concerning the electrical stimulation, data of cell population and GAGs expression were obtained from the paper [49]. Here, chondrocytes were exposed to EFs of 4 and $8 \mathrm{mV} / \mathrm{cm}$ at $60 \mathrm{kHz}$ sine waveform for 8 days. The EFs were delivered daily, starting from the first day of culture, using exposure times of $30 \mathrm{~min}, 1$ and $5 \mathrm{~h}$.

\subsection{Regression model}

Using data derived from the proliferation and GAGs quantification of stimulated and non-stimulated cell cultures, a multiple regression analysis was performed to observe the effect of independent variables (MFs/EFs, time of stimulation and days of culture) over the dependent variables (proliferation and GAGs synthesis). The data analyzed in the model were the number of cells/dish and the expression of GAGs/cell in each time measured.

Data were analyzed using different models. The first analysis consisted in applying a reduced model (Eq. (1)), which was compared with the following models. Independent variables were modelled using an interactive model (Eq. (2)). Thereafter, data were analyzed through a quadratic model (Eq. (3)). Finally, data were analyzed by combining equations (2) and (3) to observe how the interaction between the predictors of each model influence the response of the dependent variables (Eq. (4)).

$$
y=\beta_{0}+\beta_{1} x_{1}+\beta_{2} x_{2}+\beta_{3} x_{3},
$$




$$
y=\beta_{0}+\beta_{1} x_{1}+\beta_{2} x_{2}+\beta_{3} x_{3}+\beta_{4} x_{1} x_{2}+\beta_{5} x_{1} x_{3}+\beta_{6} x_{2} x_{3},
$$

$$
y=\beta_{0}+\beta_{1} x_{1}+\beta_{2} x_{2}+\beta_{3} x_{3}+\beta_{4} x_{1}^{2}+\beta_{5} x_{2}^{2}+\beta_{6} x_{3}^{2},
$$

$$
\begin{aligned}
y & =\beta_{0}+\beta_{1} x_{1}+\beta_{2} x_{2}+\beta_{3} x_{3}+\beta_{4} x_{1} x_{2} \\
& +\beta_{5} x_{1} x_{3}+\beta_{6} x_{2} x_{3}+\beta_{7} x_{1}^{2}+\beta_{8} x_{2}^{2},
\end{aligned}
$$

where $y$ represents either number of cells/dish or amount of GAGs/cell, $x_{1}$ describes either MF or EF strengths, $x_{2}$ indicates days of culture $\left(D_{c}\right), x_{3}$ is stimulation time $\left(T_{s}\right)$, and $\beta_{0-9}$ are coefficients obtained from the regression analysis. A test comparing nested models was developed to observe whether the models are useful to predict the number of cells or the expression of GAGs of stimulated and non-stimulated cultures. The test consisted in corroborating the alternative and null hypothesis, which are described by Eq. (5).

$$
\begin{aligned}
& H_{0}: \beta_{0}=\beta_{1}=\beta_{2}=\beta_{3}=\beta_{4}=\beta_{5} \\
& \quad=\beta_{6}=\beta_{7}=\beta_{8}=\beta_{9}=0, \\
& H_{1}: \text { at least one of those } \beta_{i}=0 .
\end{aligned}
$$

Then, the right-skewed distribution determined by the $F$ parameter was calculated to do a comparison between $F_{\text {rejected }}$ and $F_{\text {computed. }}$. The $F_{\text {computed }}$ was calculated using Eq. (6), in which SSER is the sum of squared errors for the reduced model, SSEC is the sum of squared errors for the complete model, $k-g$ is the number of $\beta$ parameters specified in $H_{0}, k+1$ is the number of $\beta$ parameters in the complete model and $n$ is the sample size.

$$
F_{\text {computed }}=\frac{(\mathrm{SSER}-\mathrm{SSEC}) /(k-g)}{\operatorname{SSEC} /(n-(k+1))} .
$$

After analyzing the models previously described, data were transformed to stabilize residuals and avoid heteroscedasticity property. Data transformation was performed by applying the root square model to the number of cells/dish and the total of GAGs/cell (Eq. (7)). Then, transformed data were analyzed using Eq. (7), where a sensibility analysis was performed to eliminate all outliers and predictors that do not accomplish the level of significance $p \leq 0.05$.

$$
\begin{aligned}
& \sqrt{y}=\beta_{0}+\beta_{1} x_{1}+\beta_{2} x_{2}+\beta_{3} x_{3}+\beta_{4} x_{1} x_{2} \\
& +\beta_{5} x_{1} x_{3}+\beta_{6} x_{2} x_{3}+\beta_{7} x_{1}^{2}+\beta_{8} x_{2}^{2}+\beta_{9} x_{3}^{2} .
\end{aligned}
$$

Experimental data was analyzed using Minitab 18.1 (Minitab, Inc., PA, USA), while the equations obtained to model proliferation rate and GAG's synthesis were implemented in MATLAB R2019b (MathWorks, Natick, MA, USA).

\subsection{Statistical analysis}

All experimental analyzes were performed using an average of 3. Cell proliferation was analyzed through ANOVA. In the cases in which the data showed significance, statistical verification tests were carried out to make use of the model. The statistical tests were: analysis of variances, $F$ test, Shapiro-Wilk test and Durbin-Watson test. Data that did not meet the aforementioned assumptions were analyzed by non-parametric statistic through a $F$ test that bought the slopes of the proliferation curves. A one-way ANOVA was implemented to analyze the synthesis of GAGs, identifying the difference between groups; similarly, assumptions of normality and homogeneity of variances were verified. In addition, paired comparisons were made using the DMS test. The significant differences were considered significant with a $p \leq 0.05$. Regarding the computational data, a prediction of the fitted models was implemented, considering a $95 \%$ of confidence interval.

\section{Results}

\subsection{Magnetic stimulation}

Data obtained from proliferation and GAGs quantification assays to perform the regression analysis are shown in Table 1. A comparison was performed between experimental data and prediction models regarding cell number and GAGs production. On the one hand, differences in cell proliferation were found at days 5 and 8 between non-stimulated and stimulated cultures applying $2 \mathrm{mT}$ for $1 \mathrm{~h}$. On the other hand, differences in GAGs synthesis were found at day 5 between non-stimulated and stimulated cultures applying $2 \mathrm{mT}$ for $5 \mathrm{~h}$, while at day 8 there were differences between non-stimulated and stimulated cultures applying $2 \mathrm{mT}$ during 1,3 and $5 \mathrm{~h}$.

Coefficients obtained from the reduced model for both number of cells/dish and content of GAGs/cell are in Eqs. (8) and (9). Results demonstrated that the reduced model can explain both number of cells/dish and concentration of GAGs/cell (Fig. 1). 
Table 1. Proliferation rate and GAGs quantification of chondrocytes stimulated with MFs

\begin{tabular}{|c|c|c|c|c|}
\hline $\begin{array}{l}\text { Field } \\
{[\mathrm{mT}]}\end{array}$ & $\mid \begin{array}{c}\text { Day } \\
\text { of culture }\end{array}$ & $\begin{array}{c}\text { Time } \\
\text { of exposure }[\mathrm{h}]\end{array}$ & $\begin{array}{l}\mathrm{N}^{\mathrm{o}} \\
\text { Cells }\end{array}$ & $\begin{array}{c}\text { GAGS/cell } \\
\text { [pg/cell] }\end{array}$ \\
\hline 1 & 2 & 3 & 4 & 5 \\
\hline 0 & 2 & 0 & 41500 & 43 \\
\hline 0 & 2 & 0 & 43000 & 39 \\
\hline 0 & 2 & 0 & 37500 & 40 \\
\hline 0 & 5 & 0 & 58500 & 32 \\
\hline 0 & 5 & 0 & 59500 & 26 \\
\hline 0 & 5 & 0 & 65000 & 31 \\
\hline 0 & 8 & 0 & 154500 & 20 \\
\hline 0 & 8 & 0 & 123000 & 24 \\
\hline 0 & 8 & 0 & 114500 & 26 \\
\hline 1 & 2 & 1 & 36000 & 61 \\
\hline 1 & 2 & 1 & 31000 & 52 \\
\hline 1 & 2 & 1 & 35500 & 46 \\
\hline 1 & 5 & 1 & 62500 & 34 \\
\hline 1 & 5 & 1 & 46500 & 48 \\
\hline 1 & 5 & 1 & 43000 & 57 \\
\hline 1 & 8 & 1 & 102000 & 26 \\
\hline 1 & 8 & 1 & 102000 & 23 \\
\hline 1 & 8 & 1 & 110500 & 26 \\
\hline 1 & 2 & 3 & 32500 & 47 \\
\hline 1 & 2 & 3 & 47500 & 36 \\
\hline 1 & 2 & 3 & 29500 & 61 \\
\hline 1 & 5 & 3 & 58500 & 28 \\
\hline 1 & 5 & 3 & 48500 & 46 \\
\hline 1 & 5 & 3 & 39500 & 47 \\
\hline 1 & 8 & 3 & 98000 & 27 \\
\hline 1 & 8 & 3 & 113000 & 23 \\
\hline 1 & 8 & 3 & 109000 & 25 \\
\hline 1 & 2 & 5 & 32000 & 44 \\
\hline 1 & 2 & 5 & 14500 & 87 \\
\hline 1 & 2 & 5 & 33000 & 36 \\
\hline 1 & 5 & 5 & 60000 & 33 \\
\hline 1 & 5 & 5 & 58500 & 37 \\
\hline 1 & 5 & 5 & 61500 & 34 \\
\hline 1 & 8 & 5 & 85000 & 24 \\
\hline 1 & 8 & 5 & 109000 & 28 \\
\hline 1 & 8 & 5 & 103500 & 25 \\
\hline 2 & 2 & 1 & 30500 & 26 \\
\hline 2 & 2 & 1 & 27500 & 78 \\
\hline 2 & 2 & 1 & 29500 & 83 \\
\hline 2 & 5 & 1 & 37500 & 55 \\
\hline 2 & 5 & 1 & 46500 & 38 \\
\hline 2 & 5 & 1 & 37500 & 54 \\
\hline 2 & 8 & 1 & 95500 & 28 \\
\hline 2 & 8 & 1 & 62000 & 43 \\
\hline 2 & 8 & 1 & 84500 & 33 \\
\hline 2 & 2 & 3 & 37000 & 58 \\
\hline 2 & 2 & 3 & 37000 & 43 \\
\hline 2 & 2 & 3 & 43500 & 40 \\
\hline 2 & 5 & 3 & 90000 & 19 \\
\hline 2 & 5 & 3 & 61000 & 28 \\
\hline 2 & 5 & 3 & 67500 & 33 \\
\hline 2 & 8 & 3 & 189500 & 11 \\
\hline
\end{tabular}

Table 1 continued

\begin{tabular}{|c|c|c|c|c|}
\hline $\mathbf{1}$ & $\mathbf{2}$ & $\mathbf{3}$ & $\mathbf{4}$ & $\mathbf{5}$ \\
\hline 2 & 8 & 3 & 180500 & 11 \\
\hline 2 & 8 & 3 & 134500 & 14 \\
\hline 2 & 2 & 5 & 27000 & 71 \\
\hline 2 & 2 & 5 & 33000 & 57 \\
\hline 2 & 2 & 5 & 27000 & 77 \\
\hline 2 & 5 & 5 & 74000 & 50 \\
\hline 2 & 5 & 5 & 72000 & 56 \\
\hline 2 & 5 & 5 & 64500 & 62 \\
\hline 2 & 8 & 5 & 126500 & 39 \\
\hline 2 & 8 & 5 & 145500 & 33 \\
\hline 2 & 8 & 5 & 111000 & 41 \\
\hline
\end{tabular}

$\mathrm{N}^{0}$ Cells $/$ dish $=-2286-365 M F+13873 D_{c}+1077 T_{s}$,

GAGs $/$ cell $=54.87+5.27 M F-4.56 D_{c}+0.47 T_{s}$.

Coefficients obtained from the interactive model for both number of cells/dish and content of GAGs/cell are in Eqs. (10) and (11). Results demonstrated that the interactive model could explain the number of cells/dish, but it cannot explain the concentration of GAGs/cell $\left(F_{\text {rejection }}=2.76>F_{\text {computed }}=0.48\right)($ Fig. 2$)$.

№ Cells/dish $=17316-14831 M F+11947 D_{c}-10043 T_{s}$

$$
\begin{gathered}
+595 M F * D_{c}+7154 M F * T_{s}+452 D_{c} * T_{s}, \\
\text { GAGs/cell }=48.04+8.96 M F-3.08 D_{c}+0.64 T_{s} \\
-0.88 M F * D_{c}+0.43 M F * T_{s}-0.14 D_{c} * T_{s}
\end{gathered}
$$

Regarding the quadratic model, the coefficients obtained for number of cells/dish and content of GAGs/cell are in Eqs. (12) and (13). Results demonstrated that the quadratic model could explain both number of cells/dish and concentration of GAGs/cell (Fig. 3).

$$
\begin{gathered}
\text { № Cells/dish }=45024-78172 M F-5571 D_{c} \\
+27000 T_{s}+29391 M F^{2}+1944 D_{c}^{2}-3997 T_{s}^{2}, \\
\text { GAGs/cell }=52.98+38.2 M F-4.01 D_{c} \\
-18.47 T_{s}-11.25 M F^{2}-0.056 D_{c}^{2}+3.13 T_{s}^{2} .
\end{gathered}
$$

Applying the combined model to the data, coefficients obtained for number of cells/dish and content of GAGs/cell are in Eqs. (14) and (15). Results demonstrated that the combined model could explain both number of cells/dish and concentration of GAGs/cell (Fig. 4). 


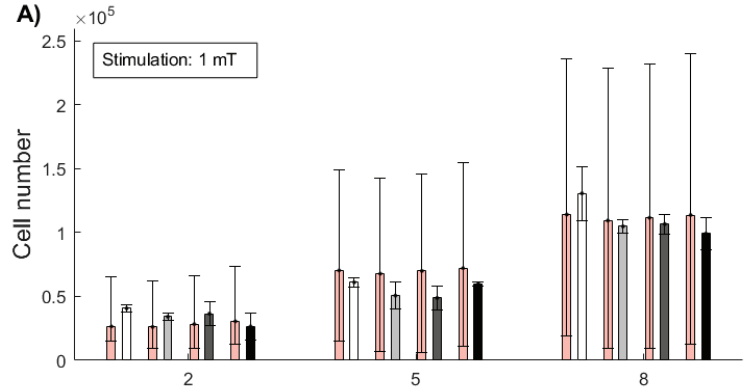

B)

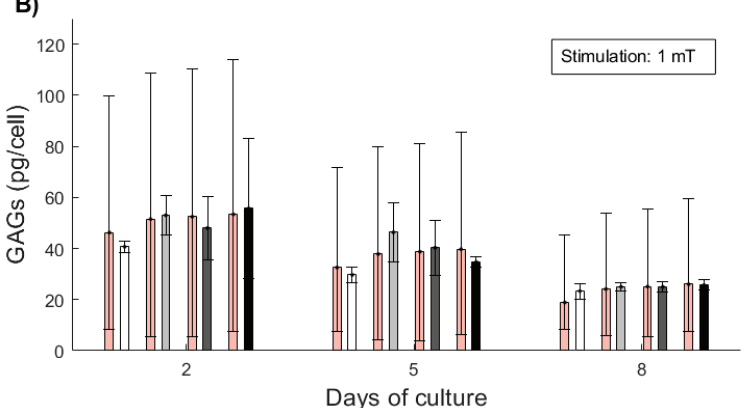

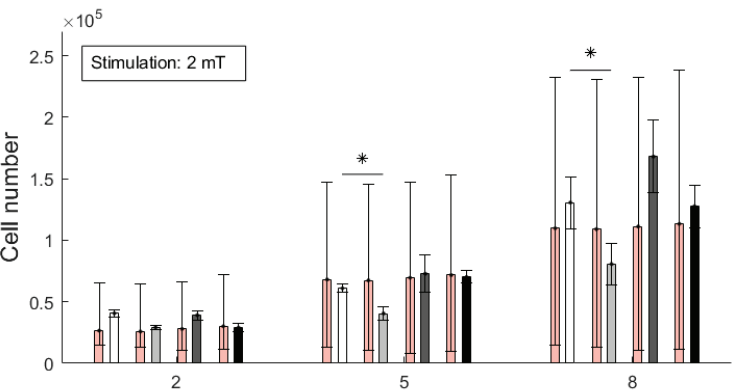

Days of culture

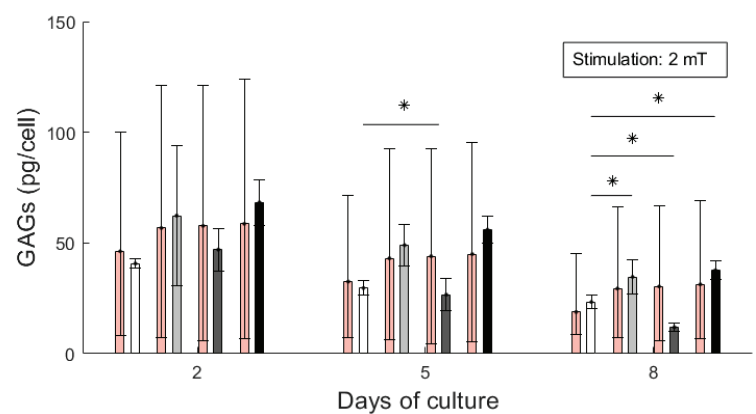

$\square$ Non-stimulated $\square$ 1h $\square$ 3h $\square$ 5h $\square$ Reduced model

Fig. 1. Representative scheme of cell proliferation and GAGs synthesis of non-stimulated and stimulated cultures with MFs compared with data obtained by reduced model. Predictions (red bars) for each experimental data (grey scale bars) are located on the left side, A) Cell population of chondrocytes, B) GAGs synthesis of chondrocytes.

Each scale bar corresponds to the average of three different samples. Experimental data were statistically analyzed, evidencing significant differences between stimulation schemes and controls $\left(p<0.05^{*}\right)$.

The prediction probability of the model was evidenced with error bars, considering a confidence interval of $95 \%$

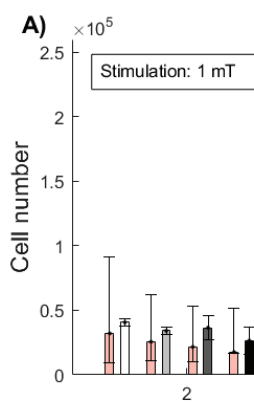

B)

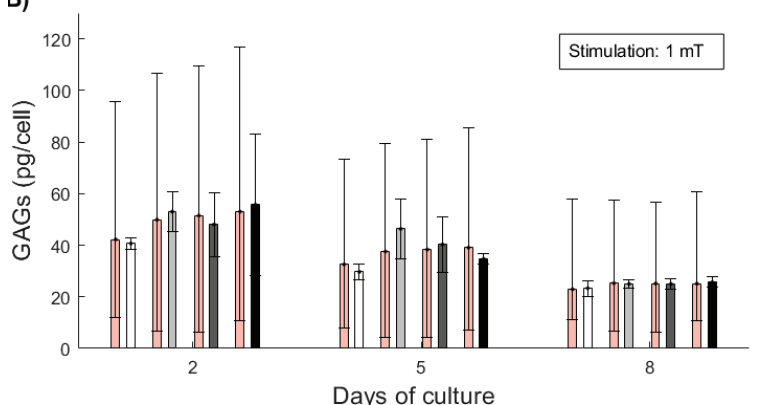

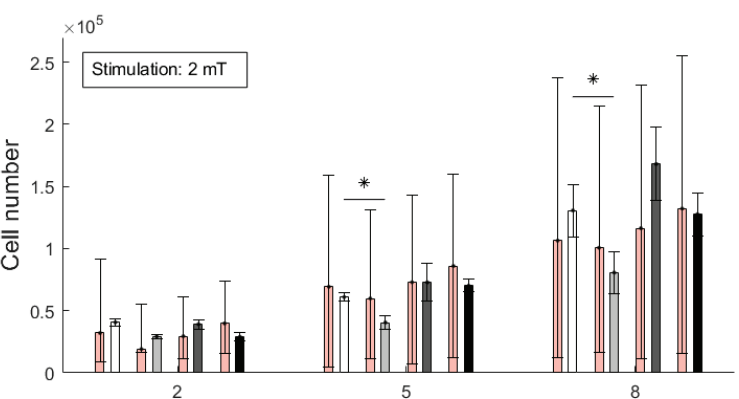

Days of culture

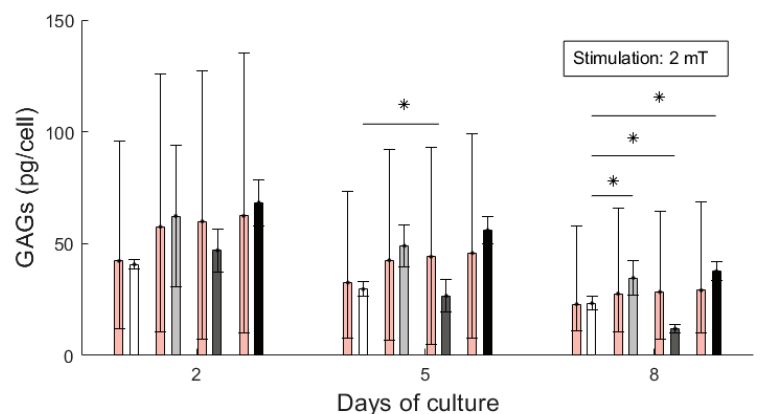

Non-stimulated $\square$ 1h

Fig. 2. Representative scheme of cell proliferation and GAGs synthesis of non-stimulated and stimulated cultures with MFs compared with data obtained by interactive model. Predictions (red bars) for each experimental data (grey scale bars) are located on the left side, A) Cell population of chondrocytes, B) GAGs synthesis of chondrocytes.

Each scale bar corresponds to the average of three different samples. Experimental data were statistically analyzed, evidencing significant differences between stimulation schemes and controls $\left(p<0.05^{*}\right)$.

The prediction probability of the model was evidenced with error bars, considering a confidence interval of $95 \%$ 

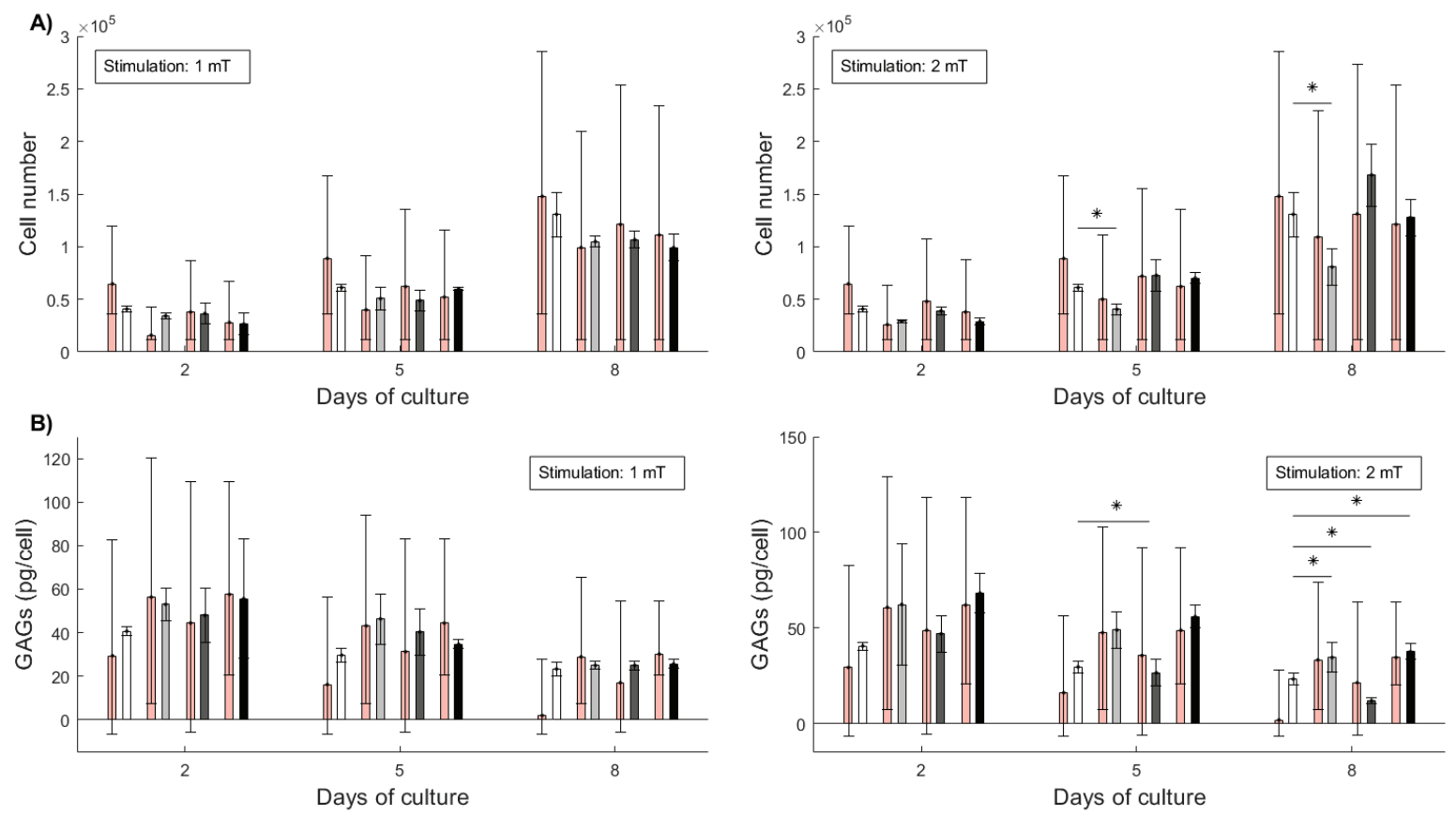

$\square$ Non-stimulated $\square$ 1h $\square$ 3h $\square$ 5h $\square$ Quadratic model

Fig. 3. Representative scheme of cell proliferation and GAGs synthesis of non-stimulated and stimulated cultures with MFs compared to data obtained by quadratic model. Predictions (red bars) for each experimental data (grey scale bars) are located on the left side, A) Cell population of chondrocytes, B) GAGs synthesis of chondrocytes.

Each scale bar corresponds to the average of three different samples. Experimental data were statistically analyzed, evidencing significant differences between stimulation schemes and controls $\left(p<0.05^{*}\right)$.

The prediction probability of the model was evidenced with error bars, considering a confidence interval of $95 \%$
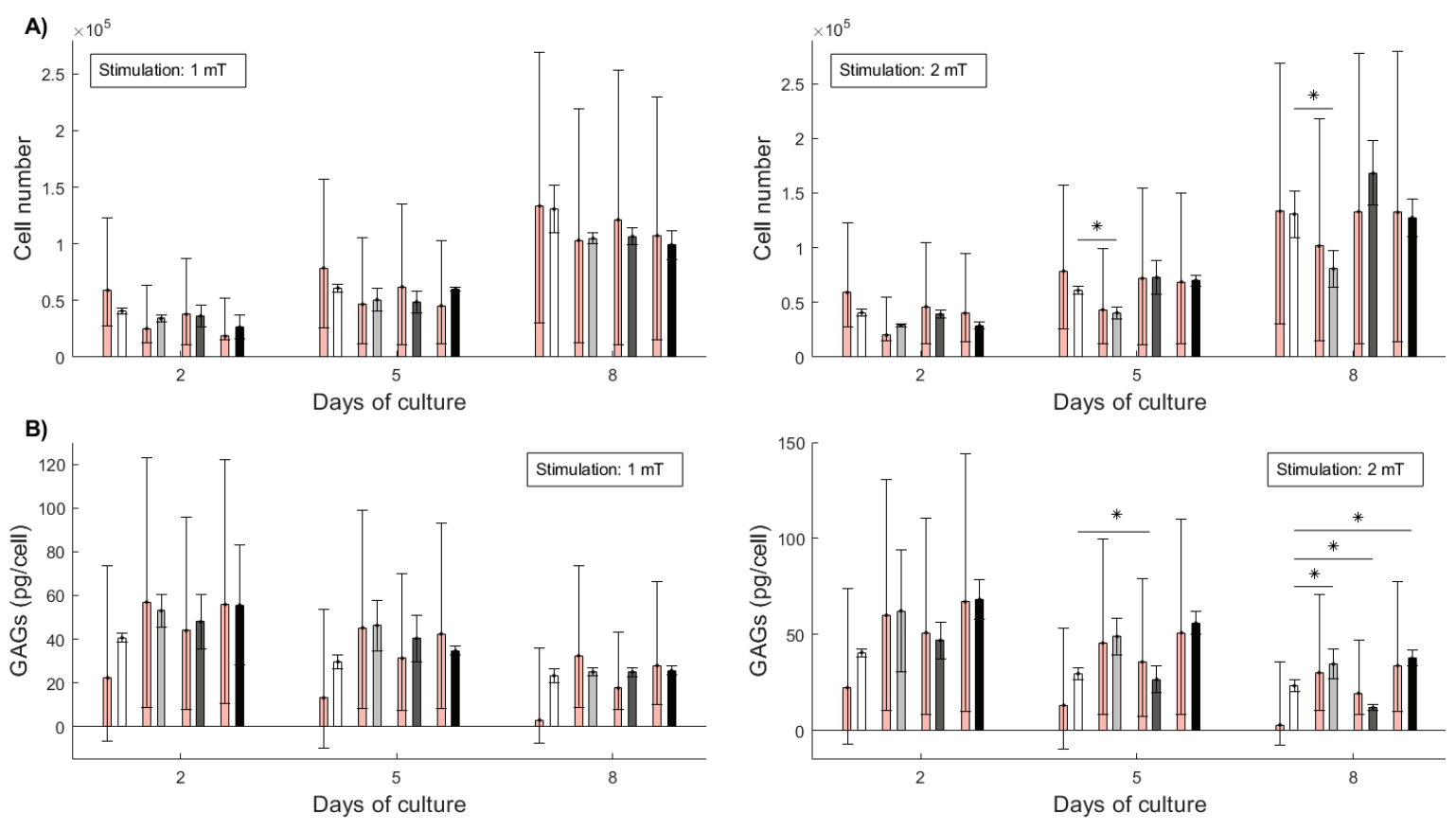

Non-stimulated $\square$ 1h

hh $\square$ Combined model

Fig. 4. Representative scheme of cell proliferation and GAGs synthesis of non-stimulated and stimulated cultures with MFs compared to data obtained by combined model. Predictions (red bars) for each experimental data (grey scale bars) are located on the left side, A) Cell population of chondrocytes, B) GAGs synthesis of chondrocytes.

Each scale bar corresponds to the average of three different samples. Experimental data were statistically analyzed, evidencing significant differences between stimulation schemes and controls $\left(p<0.05^{*}\right)$.

The prediction probability of the model was evidenced with error bars, considering a confidence interval of $95 \%$ 


$$
\begin{gathered}
\text { № Cells } / \text { dish }=54656-55989 M F-7493 D_{c} \\
+14679 T_{s}+595 M F * D_{c}+6708 M F * T_{s} \\
+452 D_{c} * T_{s}+14297 M F^{2}+1944 D_{c}^{2}-3997 T_{s}^{2},
\end{gathered}
$$$$
\mathrm{GAGs} / \mathrm{cell}=45.56+50.02 \mathrm{MF}-2.52 D_{c}
$$

$$
\begin{gathered}
-20.81 T_{s}-0.875 M F * D_{c}+2.03 M F * T_{s}-0.14 D_{c} \\
* T_{s}-15.82 M F^{2}-0.056 D_{c}^{2}+3.13 T_{s}^{2} .
\end{gathered}
$$

The simulation of the reduced, interactive, quadratic and combined models evidenced the determination coefficients R-squared $\left(R^{2}\right)$ and adjusted $R$-squared

Table 2. Constants and coefficients obtained from the regression output of stimulated cultures with MFs

\begin{tabular}{|l|l|c|c|c|c|c|}
\hline \multicolumn{2}{|l|}{} & $\begin{array}{c}\text { Reduced } \\
\text { model }\end{array}$ & $\begin{array}{c}\text { Interactive } \\
\text { model }\end{array}$ & $\begin{array}{c}\text { Quadratic } \\
\text { model }\end{array}$ & $\begin{array}{c}\text { Combined } \\
\text { model }\end{array}$ & $\begin{array}{c}\text { Root square } \\
\text { model }\end{array}$ \\
\hline \multirow{2}{*}{$R^{2}$} & No cell/dish & 72.78 & 77.94 & 83.23 & 85.28 & 92.04 \\
\cline { 2 - 7 } & GAGs /cell & 49.12 & 50.41 & 59.58 & 61.59 & 70.95 \\
\hline \multirow{2}{*}{$R_{A D J}^{2}$} & No cell/dish & 71.40 & 75.70 & 81.43 & 82.78 & 91.29 \\
\cline { 2 - 7 } & GAGs /cell & 46.53 & 45.10 & 55.25 & 55.07 & 67.72 \\
\hline
\end{tabular}

Table 3. Constants and coefficients obtained from the regression output in cell cultures stimulated with MFs. $F_{\text {rejected }}$ was calculated with an $\alpha=0.05$

\begin{tabular}{|l|l|c|c|c|}
\hline \multicolumn{2}{|c|}{} & $\begin{array}{c}\text { Interactive } \\
\text { model }\end{array}$ & $\begin{array}{c}\text { Quadratic } \\
\text { model }\end{array}$ & $\begin{array}{c}\text { Combined } \\
\text { model }\end{array}$ \\
\hline \multirow{2}{*}{ SSER } & No cell/dish & \multicolumn{3}{|c|}{$2.73 \mathrm{E}+10$} \\
\cline { 2 - 5 } & GAGs/cell & & $9 \mathrm{E}+3$ \\
\hline \multirow{2}{*}{ SSEC } & No cell/dish & $2.21 \mathrm{E}+10$ & $1.68 \mathrm{E}+10$ & $1.48 \mathrm{E}+10$ \\
\cline { 2 - 6 } & GAGs /cell & $9 \mathrm{E}+3$ & $7 \mathrm{E}+3$ & $6 \mathrm{E}+3$ \\
\hline \multirow{2}{*}{$F_{\text {rejected }}$} & No cell/dish & 2.76 & 2.76 & 2.25 \\
\cline { 2 - 6 } & GAGs /cell & & 11.36 & 7.50 \\
\hline \multirow{2}{*}{$F_{\text {computed }}$} & No cell/dish & 4.36 & 4.83 & 3.04 \\
\cline { 2 - 6 } & GAGs $/$ cell & 0.48 & \multicolumn{3}{|c}{} \\
\hline
\end{tabular}
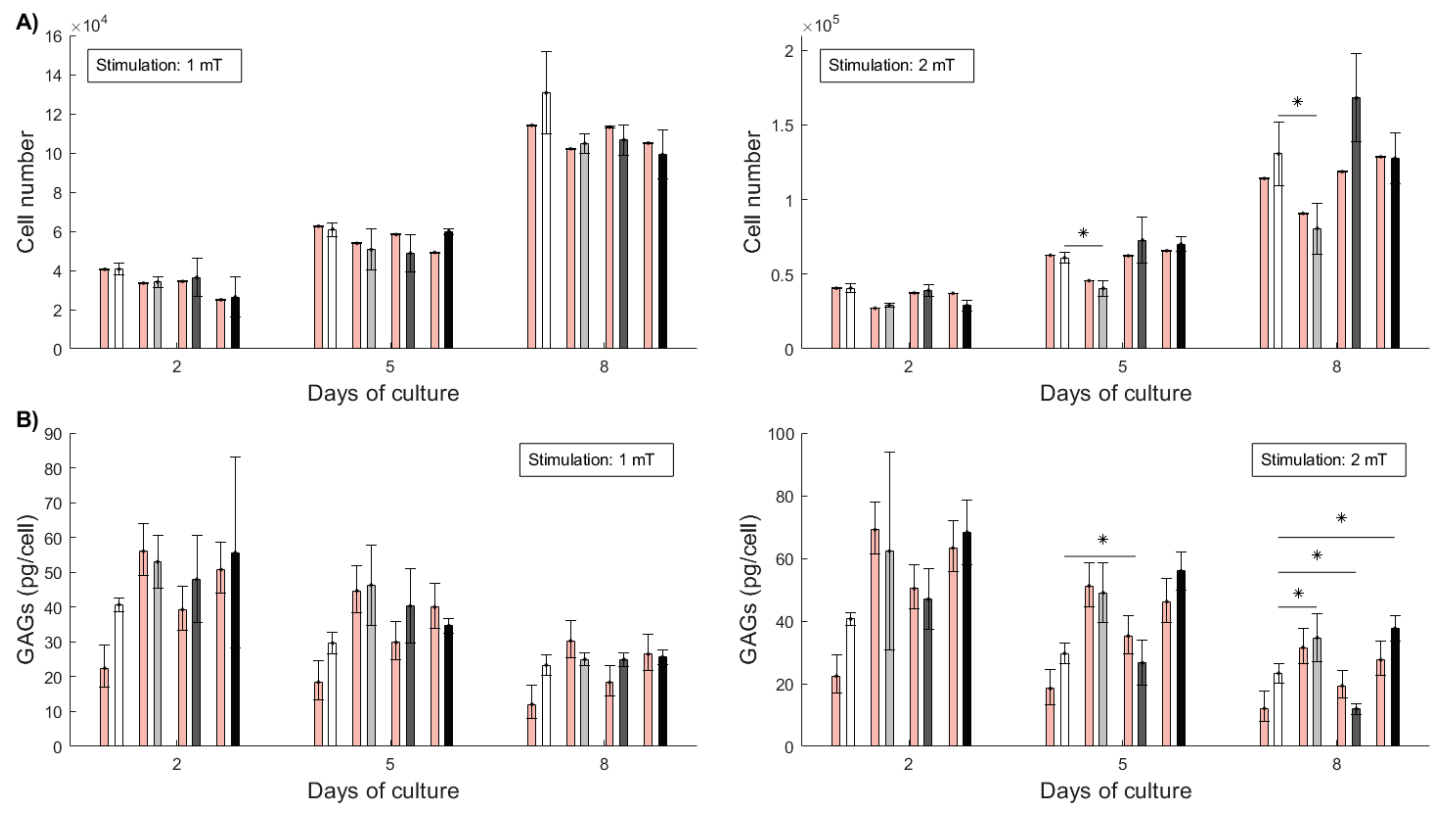

Non-stimulated $\square$ 1h $\square$

Fig. 5. Representative scheme of cell proliferation and GAGs synthesis of non-stimulated and stimulated cultures with MFs compared to data obtained by the root square model. Predictions (red bars) for each experimental data (grey scale bars) are located on the left side, A) Cell population of chondrocytes, B) GAGs synthesis of chondrocytes. Each scale bar corresponds to the average of three different samples. Experimental data were statistically analyzed, evidencing significant differences between stimulation schemes and controls $(p<0.05 *)$. The prediction probability of the model was evidenced with error bars, considering a confidence interval of $95 \%$ 
$\left(R_{A D J}^{2}\right)$ for number of cells/dish and content of GAGs/ cell (Table 2). Here, $R_{2}$ provides information about how much the variation in the dependent variable could be explained by the model. In addition, the difference between $R^{2}$ and $R_{A D J}^{2}$ considers the sample size and the number of parameters used in the model.

Constants and coefficients to calculate right-skewed distribution $(F)$ of interactive, quadratic and combined models are in Table 3. Models that evidenced an $F_{\text {computed }}>F_{\text {rejected }}$ were intended to reject $H_{0}$, concluding that interactive, quadratic and combined terms contribute to the prediction of number of cells/dish and GAGs/cell.

Finally, data were transformed using the root square model and analyzed by using the combined model. Coefficients obtained from the model for both number of cells/dish and content of GAGs/cell were used in Eqs. (16) and (17) (Fig. 5). These equations were obtained by eliminating outliers and predictors that do not accomplish levels of significance $p \leq 0.05$. Coefficients $R^{2}$ and $R_{A D J}^{2}$ for number of cells/dish and content of GAGs/cell are in Table 2.

$$
\begin{aligned}
& \sqrt{\mathrm{N}^{\mathrm{o}} \frac{\text { Cells }}{\text { dish }}}=194.02-31.50 M F+13.21 M F \\
& * T_{s}+1.23 D_{c} * T_{s}+2.15 D_{c}^{2}-3.65 T_{s}^{2}, \\
& \sqrt{\frac{\mathrm{GAGs}}{\text { cell }}}=6.21+3.95 M F-1.65 T_{s}-0.12 M F \\
& * D_{c}-0.96 M F^{2}-0.021 D_{c}^{2}+0.26 T_{s}^{2}
\end{aligned}
$$

\subsection{Electrical stimulation}

Data collected from proliferation and GAGs quantification assays to perform the regression analysis are listed in Table 4. On one hand, differences in proliferation rate were found at days 4 and 6 between nonstimulated and stimulated cultures applying $4 \mathrm{mV} / \mathrm{cm}$ for $30 \mathrm{~min}$. Finally, a decrease in cell population was observed in cell cultures stimulated with 4 and $8 \mathrm{mV} / \mathrm{cm}$ during $5 \mathrm{~h}$ at day 6 . On the other hand, a decrease in GAGs synthesis were found at days 2, 4 and 6 in both non-stimulated and stimulated cultures during $30 \mathrm{~min}$ and $1 \mathrm{~h}$, while a constant synthesis of GAGs was observed in stimulated cultures during $5 \mathrm{~h}$ compared to non-stimulated cultures; specially, at day 6 were GAGs were higher in stimulated cultures compared to

\begin{tabular}{|c|c|c|c|c|}
\hline $\begin{array}{c}\text { Field } \\
{[\mathrm{mV} / \mathrm{cm}]}\end{array}$ & $\begin{array}{c}\text { Day } \\
\text { of culture }\end{array}$ & $\begin{array}{c}\text { Time } \\
\text { of exposure }[\mathrm{h}]\end{array}$ & $\begin{array}{c}\mathrm{N}^{\mathrm{o}} \\
\text { Cells } \\
\end{array}$ & $\begin{array}{c}\text { GAGS/cell } \\
\text { [pg/cell] }\end{array}$ \\
\hline 1 & 2 & 3 & 4 & 5 \\
\hline 0 & 2 & 0.5 & 55000 & 246.665 \\
\hline 0 & 2 & 0.5 & 70000 & 315.700 \\
\hline 0 & 2 & 0.5 & 70000 & 195.027 \\
\hline 0 & 4 & 0.5 & 85000 & 262.999 \\
\hline 0 & 4 & 0.5 & 110000 & 147.378 \\
\hline 0 & 4 & 0.5 & 100000 & 182.594 \\
\hline 0 & 6 & 0.5 & 205000 & 42.652 \\
\hline 0 & 6 & 0.5 & 180000 & 60.684 \\
\hline 0 & 6 & 0.5 & 150000 & 68.547 \\
\hline 0 & 8 & 0.5 & 705000 & 26.223 \\
\hline 0 & 8 & 0.5 & 420000 & 43.101 \\
\hline 0 & 8 & 0.5 & 475000 & 36.761 \\
\hline 4 & 2 & 0.5 & 50000 & 92.821 \\
\hline 4 & 2 & 0.5 & 40000 & 138.462 \\
\hline 4 & 2 & 0.5 & 65000 & 95.069 \\
\hline 4 & 4 & 0.5 & 165000 & 53.768 \\
\hline 4 & 4 & 0.5 & 195000 & 33.005 \\
\hline 4 & 4 & 0.5 & 225000 & 54.815 \\
\hline 4 & 6 & 0.5 & 250000 & 34.462 \\
\hline 4 & 6 & 0.5 & 285000 & 35.178 \\
\hline 4 & 6 & 0.5 & 290000 & 33.687 \\
\hline 4 & 8 & 0.5 & 540000 & 29.250 \\
\hline 4 & 8 & 0.5 & 435000 & 28.647 \\
\hline 4 & 8 & 0.5 & 825000 & 16.814 \\
\hline 8 & 2 & 0.5 & 55000 & 280.794 \\
\hline 8 & 2 & 0.5 & 75000 & 212.742 \\
\hline 8 & 2 & 0.5 & 65000 & 246.784 \\
\hline 8 & 4 & 0.5 & 90000 & 199.090 \\
\hline 8 & 4 & 0.5 & 125000 & 136.519 \\
\hline 8 & 4 & 0.5 & 115000 & 166.197 \\
\hline 8 & 6 & 0.5 & 165000 & 48.329 \\
\hline 8 & 6 & 0.5 & 180000 & 73.504 \\
\hline 8 & 6 & 0.5 & 205000 & 45.779 \\
\hline 8 & 8 & 0.5 & 530000 & 19.642 \\
\hline 8 & 8 & 0.5 & 375000 & 46.564 \\
\hline 8 & 8 & 0.5 & 790000 & 22.265 \\
\hline 0 & 2 & 1 & 65000 & 394.625 \\
\hline 0 & 2 & 1 & 80000 & 366.894 \\
\hline 0 & 2 & 1 & 70000 & 293.895 \\
\hline 0 & 4 & 1 & 150000 & 288.551 \\
\hline 0 & 4 & 1 & 105000 & 235.495 \\
\hline 0 & 4 & 1 & 145000 & 290.102 \\
\hline 0 & 6 & 1 & 215000 & 72.137 \\
\hline 0 & 6 & 1 & 185000 & 108.034 \\
\hline 0 & 6 & 1 & 190000 & 73.333 \\
\hline 0 & 8 & 1 & 455000 & 15.561 \\
\hline 0 & 8 & 1 & 495000 & 34.302 \\
\hline 0 & 8 & 1 & 520000 & 19.512 \\
\hline 4 & 2 & 1 & 75000 & 511.945 \\
\hline 4 & 2 & 1 & 70000 & 421.745 \\
\hline 4 & 2 & 1 & 80000 & 492.036 \\
\hline 4 & 4 & 1 & 110000 & 343.003 \\
\hline 4 & 4 & 1 & 100000 & 477.816 \\
\hline 4 & 4 & 1 & 100000 & 276.976 \\
\hline
\end{tabular}
controls.
Table 4. Proliferation rate and GAGs quantification of chondrocytes stimulated with Efs 
Table 2 continued

Table 2 continued

\begin{tabular}{|c|c|c|c|c|}
\hline 1 & 2 & 3 & 4 & 5 \\
\hline 4 & 6 & 1 & 160000 & 63.590 \\
\hline 4 & 6 & 1 & 175000 & 63.590 \\
\hline 4 & 6 & 1 & 175000 & 57.949 \\
\hline 4 & 8 & 1 & 490000 & 16.647 \\
\hline 4 & 8 & 1 & 440000 & 37.538 \\
\hline 4 & 8 & 1 & 505000 & 18.703 \\
\hline 8 & 2 & 1 & 70000 & 328.498 \\
\hline 8 & 2 & 1 & 65000 & 351.048 \\
\hline 8 & 2 & 1 & 60000 & 627.986 \\
\hline 8 & 4 & 1 & 125000 & 390.358 \\
\hline 8 & 4 & 1 & 105000 & 189.846 \\
\hline 8 & 4 & 1 & 160000 & 29.670 \\
\hline 8 & 6 & 1 & 195000 & 112.821 \\
\hline 8 & 6 & 1 & 190000 & 216.850 \\
\hline 8 & 6 & 1 & 215000 & 184.615 \\
\hline 8 & 8 & 1 & 445000 & 32.017 \\
\hline 8 & 8 & 1 & 480000 & 64.263 \\
\hline 8 & 8 & 1 & 535000 & 55.092 \\
\hline 0 & 2 & 5 & 55000 & 295.353 \\
\hline 0 & 2 & 5 & 85000 & 146.473 \\
\hline 0 & 2 & 5 & 67500 & 253.347 \\
\hline 0 & 4 & 5 & 162500 & 89.888 \\
\hline 0 & 4 & 5 & 147500 & 122.920 \\
\hline 0 & 4 & 5 & 217500 & 67.484 \\
\hline 0 & 6 & 5 & 317500 & 26.122 \\
\hline 0 & 6 & 5 & 372500 & 31.766 \\
\hline 0 & 6 & 5 & 295000 & 31.863 \\
\hline 0 & 8 & 5 & 735000 & 26.335 \\
\hline 0 & 8 & 5 & 430000 & 50.475 \\
\hline 0 & 8 & 5 & 425000 & 43.446 \\
\hline
\end{tabular}

\begin{tabular}{|c|c|c|c|c|}
\hline $\mathbf{1}$ & $\mathbf{2}$ & $\mathbf{3}$ & $\mathbf{4}$ & $\mathbf{5}$ \\
\hline 4 & 2 & 5 & 60000 & 77.350 \\
\hline 4 & 2 & 5 & 35000 & 106.960 \\
\hline 4 & 2 & 5 & 30000 & 180.342 \\
\hline 4 & 4 & 5 & 40000 & 83.974 \\
\hline 4 & 4 & 5 & 40000 & 100.000 \\
\hline 4 & 4 & 5 & 95000 & 50.202 \\
\hline 4 & 6 & 5 & 40000 & 116.026 \\
\hline 4 & 6 & 5 & 45000 & 105.983 \\
\hline 4 & 6 & 5 & 90000 & 45.869 \\
\hline 4 & 8 & 5 & 145000 & 45.270 \\
\hline 4 & 8 & 5 & 155000 & 36.559 \\
\hline 4 & 8 & 5 & 225000 & 16.638 \\
\hline 8 & 2 & 5 & 45000 & 108.832 \\
\hline 8 & 2 & 5 & 30000 & 184.615 \\
\hline 8 & 2 & 5 & 25000 & 206.154 \\
\hline 8 & 4 & 5 & 15000 & 437.607 \\
\hline 8 & 4 & 5 & 60000 & 100.855 \\
\hline 8 & 4 & 5 & 35000 & 169.231 \\
\hline 8 & 6 & 5 & 55000 & 98.368 \\
\hline 8 & 6 & 5 & 90000 & 80.057 \\
\hline 8 & 6 & 5 & 40000 & 225.000 \\
\hline 8 & 8 & 5 & 55000 & 300.962 \\
\hline 8 & 8 & 5 & 55000 & 300.962 \\
\hline 8 & 8 & 5 & 55000 & 300.962 \\
\hline & & & & \\
\hline
\end{tabular}

Coefficients obtained from the reduced model for both number of cells/dish and content of GAGs/ cell were used in Eqs. (18) and (19). Results demonstrated that the reduced model could explain both

A)
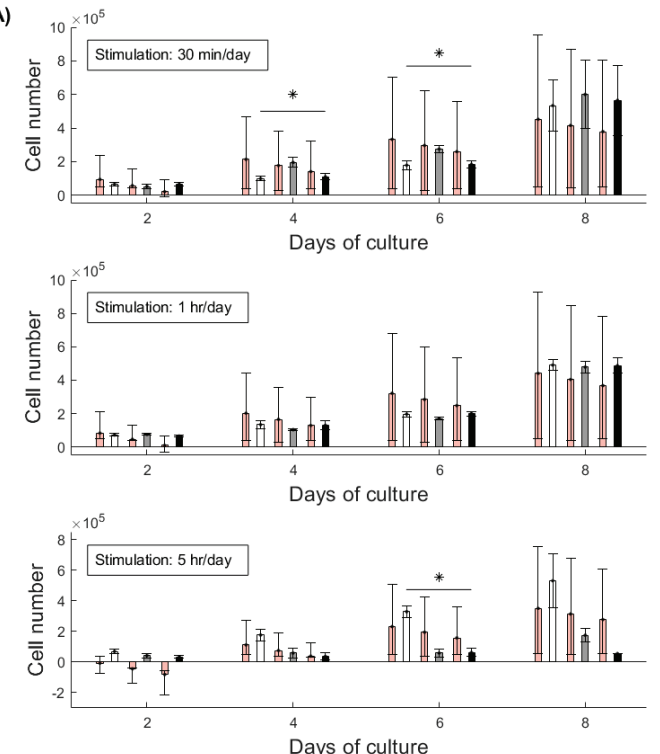

B)
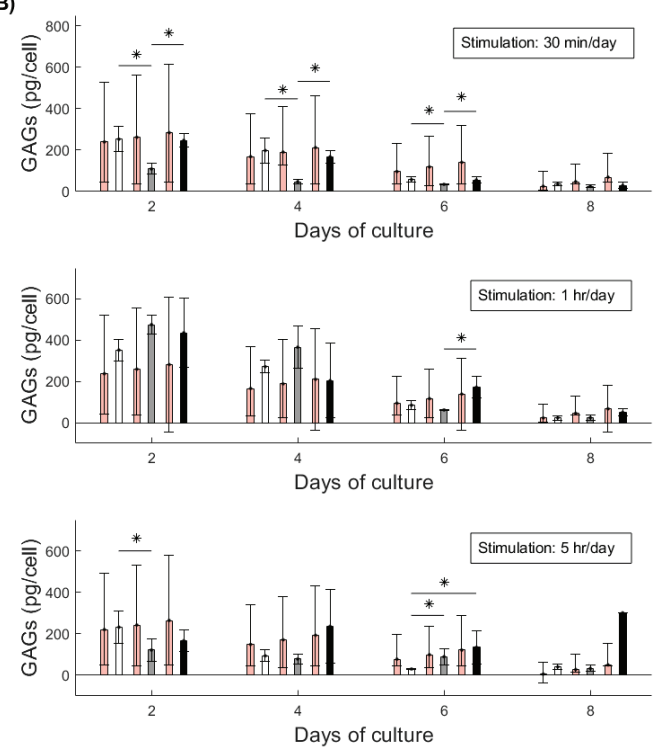

$\square$ Non-stimulated $\square 4 \mathrm{mV} / \mathrm{cm}$

$8 \mathrm{mV} / \mathrm{cm} \square$ Reduced model

Fig. 6. Representative scheme of cell proliferation and GAGs synthesis of non-stimulated and stimulated cultures with EFs compared to data obtained by the reduced model. Predictions (red bars) for each experimental data (grey scale bars) are located on the left side,

A) Cell population of chondrocytes, B) GAGs synthesis of chondrocytes. Each scale bar corresponds to the average of three different samples. Experimental data were statistically analyzed, evidencing significant differences between stimulation schemes and controls $\left(p<0.05^{*}\right)$. The prediction probability of the model was evidenced with error bars, considering a confidence interval of $95 \%$ 
number of cells/dish and concentration of GAGs/ cell (Fig. 6).

$$
\begin{gathered}
\text { № Cells/dish }=-14283-9149 E F \\
+59657 D_{c}-22607 T_{s}, \\
\text { GAGs } / \text { cell }=313.9+5.52 E F \\
-35.72 D_{c}-4.31 T_{s} .
\end{gathered}
$$

Coefficients obtained from the interactive model for both number of cells/dish and content of GAGs/cell are in Eqs. (20) and (21). Results demonstrated that the reduced model could explain both number of cells/dish and concentration of GAGs/cell (Fig. 7).

$$
\begin{gathered}
\text { № Cells/dish }=-230671+19646 E F \\
+91065 D_{c}+51495 T_{s}-2792 E F \\
* D_{c}-6848 E F * T_{s}-9342 D_{c} * T_{s}, \\
\text { GAGs/cell }=469.5-10.95 E F \\
-61.60 D_{c}-57.8 T_{s}+1.99 E F * D_{c} \\
+3.02 E F * T_{s}+8.28 D_{c} * T_{s} .
\end{gathered}
$$

Regarding the quadratic model, coefficients acquired for number of cells/dish and content of GAGs/cell are in Eqs. (22) and (23). Results demonstrated that the quadratic model could explain both number of cells/dish and concentration of GAGs/cell (Fig. 8).

A)
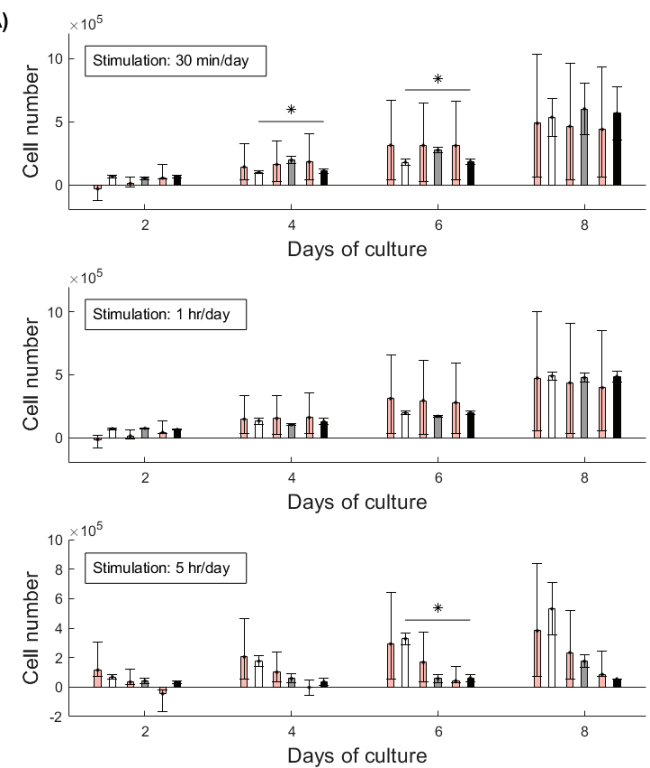

№ Cells/dish $=260332-15365 E F$

$$
\begin{gathered}
-62449 D_{c}+64329 T_{s}+777 E F^{2} \\
+12211 D_{c}^{2}+7330 T_{s}^{2}
\end{gathered}
$$

GAGs/cell $=231.6-16.92 E F$

$$
\begin{gathered}
-74.7 D_{c}+261 T_{s}+2.66 E F^{2} \\
+4.11 D_{c}^{2}-46.76 T_{s}^{2} .
\end{gathered}
$$

Applying the combined model to the data, coefficients obtained for number of cells/dish and content of GAGs/cell are in Eqs. (24) and (25). Results demonstrated that the combined model can explain both number of cells/dish and concentration of GAGs/cell (Fig. 9).

$$
\begin{gathered}
\text { № } \frac{\text { Cells }}{\text { dish }}=43944+13431 E F-31041 D_{c} \\
+9773 T_{s}-2792 E F * D_{c}-6848 E F \\
* T_{s}-9342 D_{c} * T_{s}+777 E F^{2} \\
\quad+12211 D_{c}^{2}+7330 T_{s}^{2}, \\
\frac{\text { GAGs }}{\text { cell }}=395-35.2 E F-102.6 D_{c} \\
+209.1 T_{s}+2.65 E F * D_{c}
\end{gathered}
$$

B)
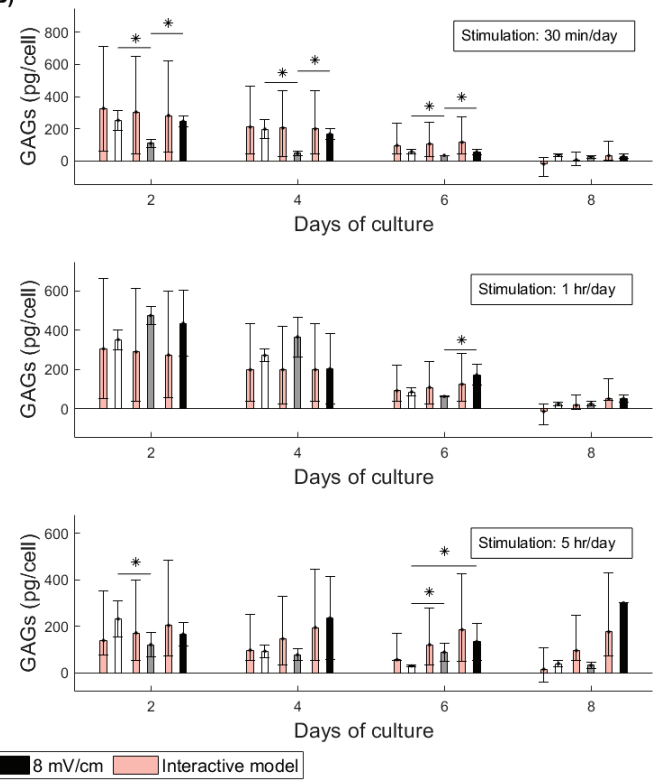

Fig. 7. Representative scheme of cell proliferation and GAGs synthesis of non-stimulated and stimulated cultures with EFs compared to data obtained by the interactive model. Predictions (red bars) for each experimental data (grey scale bars) are located on the left side, A) Cell population of chondrocytes, B) GAGs synthesis of chondrocytes. Each scale bar corresponds to the average of three different samples. Experimental data were statistically analyzed, evidencing significant differences between stimulation schemes and controls $\left(p<0.05^{*}\right)$. The prediction probability of the model was evidenced with error bars, considering a confidence interval of $95 \%$ 


$$
\begin{gathered}
+2.44 E F * T_{s}+8.12 D_{c} * T_{s} \\
+2.61 E F^{2}+4.1 D_{c}^{2}-46.48 T_{s}^{2} .
\end{gathered}
$$

Simulation of the reduced, interactive, quadratic and combined models evidenced the determination coeffi-

A)
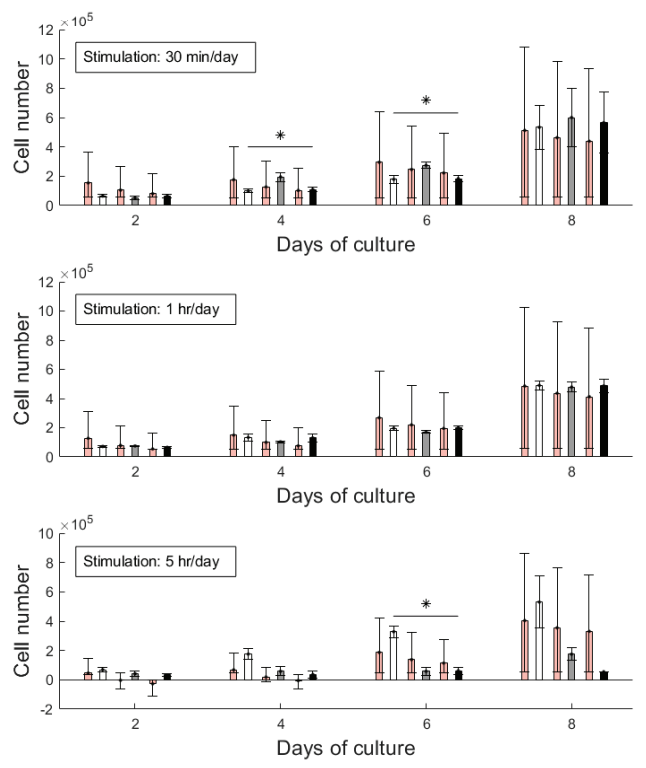

cients $R^{2}$ and $R_{A D J}^{2}$ for number of cells/dish and content of GAGs/cell (Table 5).

Constants and coefficients to calculate right-skewed distribution $(F)$ of the reduced, interactive, quadratic and combined models are in Table 6. Mod-

B)
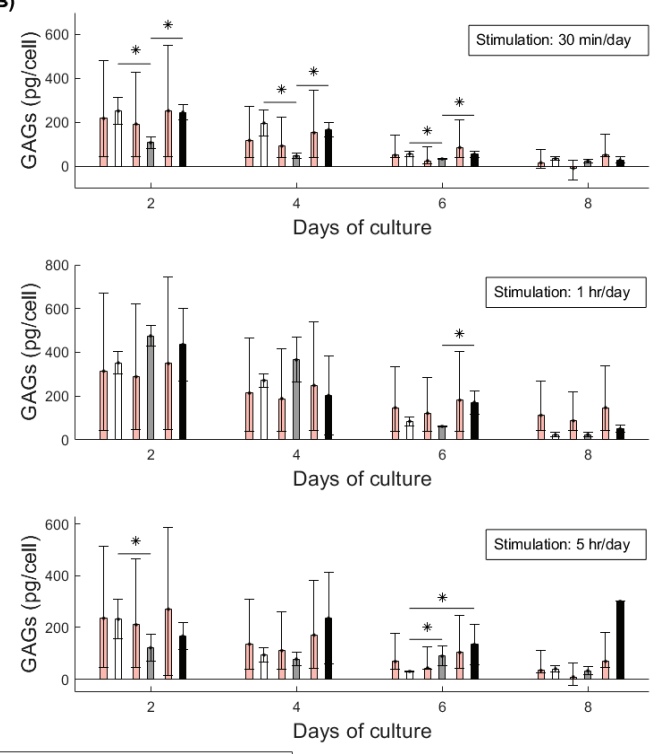

Fig. 8. Representative scheme of cell proliferation and GAGs synthesis of non-stimulated and stimulated cultures with EFs compared to data obtained by the quadratic model. Predictions (red bars) for each experimental data (grey scale bars) are located on the left side,

A) Cell population of chondrocytes, B) GAGs synthesis of chondrocytes. Each scale bar corresponds to the average of three different samples. Experimental data were statistically analyzed, evidencing significant differences between stimulation schemes and controls $\left(p<0.05^{*}\right)$.

The prediction probability of the model was evidenced with error bars, considering a confidence interval of $95 \%$

A)
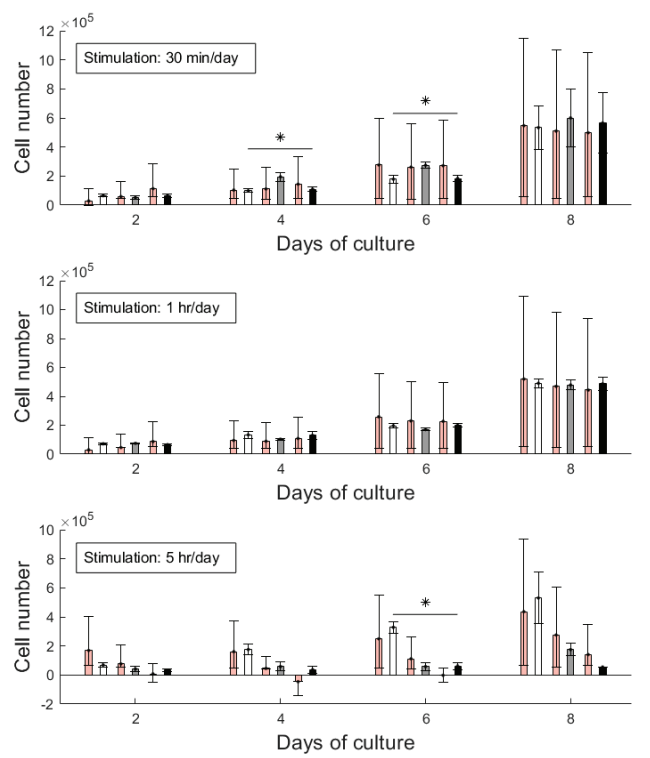

B)
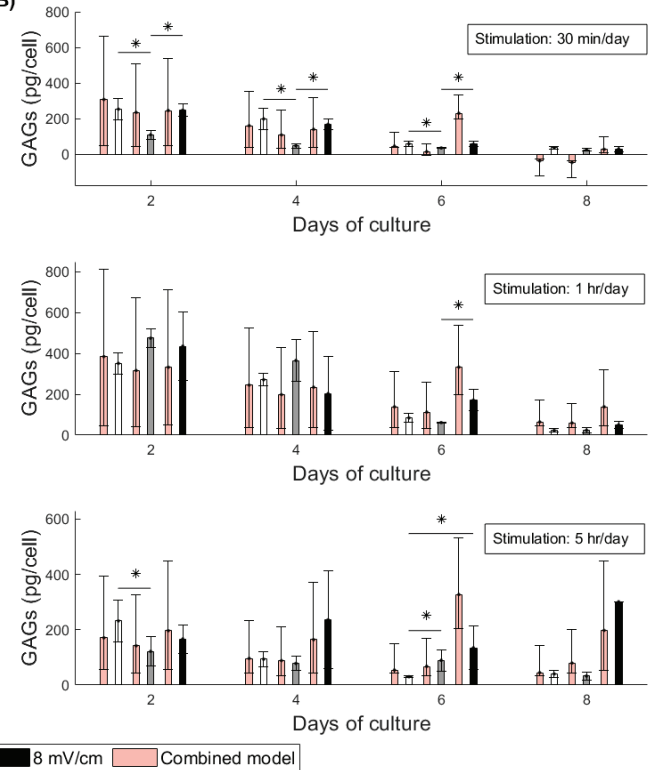

Fig. 9. Representative scheme of cell proliferation and GAGs synthesis of non-stimulated and stimulated cultures with EFs compared to data obtained by the combined model. Predictions (red bars) for each experimental data (grey scale bars) are located on the left side,

A) Cell population of chondrocytes, B) GAGs synthesis of chondrocytes. Each scale bar corresponds to the average of three different samples. Experimental data were statistically analyzed, evidencing significant differences between stimulation schemes and controls $(p<0.05 *)$. The prediction probability of the model was evidenced with error bars, considering a confidence interval of $95 \%$ 
Table 5. Constants and coefficients obtained from the regression output of stimulated cultures with EFs

\begin{tabular}{|l|l|c|c|c|c|c|}
\hline \multicolumn{2}{|c|}{} & $\begin{array}{c}\text { Reduced } \\
\text { model }\end{array}$ & $\begin{array}{c}\text { Interactive } \\
\text { model }\end{array}$ & $\begin{array}{c}\text { Quadratic } \\
\text { model }\end{array}$ & $\begin{array}{c}\text { Combined } \\
\text { model }\end{array}$ & $\begin{array}{c}\text { Root } \\
\text { square model }\end{array}$ \\
\hline \multirow{2}{*}{$R^{2}$} & No cell/dish & 61.79 & 74.34 & 69.11 & 81.66 & 88.19 \\
\cline { 2 - 7 } & GAGs /cell & 38.01 & 49.20 & 56.10 & 70.45 & 74.79 \\
\hline \multirow{2}{*}{$R_{A D J}^{2}$} & No cell/dish & 60.69 & 72.81 & 67.28 & 79.97 & 87.47 \\
\cline { 2 - 7 } & GAGs /cell & 36.22 & 46.18 & 53.39 & 67.62 & 72.66 \\
\hline
\end{tabular}

Table 6. Constants and coefficients obtained from the regression output in cell cultures stimulated with EFs. $F_{\text {rejected }}$ was calculated with an $\alpha=0.05$

\begin{tabular}{|l|l|c|c|c|}
\hline \multicolumn{2}{|c|}{} & $\begin{array}{c}\text { Interactive } \\
\text { model }\end{array}$ & $\begin{array}{c}\text { Quadratic } \\
\text { model }\end{array}$ & $\begin{array}{c}\text { Combined } \\
\text { model }\end{array}$ \\
\hline \multirow{2}{*}{ SSER } & No cell/dish & \multicolumn{3}{|c|}{$1.38 \mathrm{E}+12$} \\
\cline { 2 - 5 } & GAGs /cell & \multicolumn{3}{|c|}{$1.1 \mathrm{E}+6$} \\
\hline \multirow{2}{*}{ SSEC } & No cell/dish & $9.31 \mathrm{E}+11$ & $1.12+12$ & $6.65 \mathrm{E}+11$ \\
\cline { 2 - 5 } & GAGs $/$ cell & $97 \mathrm{E}+4$ & $92 \mathrm{E}+4$ & $70 \mathrm{E}+4$ \\
\hline \multirow{2}{*}{$F_{\text {rejected }}$} & No cell/dish & 2.68 & 2.68 & 2.17 \\
\cline { 2 - 5 }$F_{\text {computed }}$ & GAGs /cell & 16.45 & 7.98 & 17.68 \\
\cline { 2 - 5 } & No cell/dish & 7.41 & 10 & 11.32 \\
\cline { 2 - 5 } & GAGs /cell & & &
\end{tabular}

A)
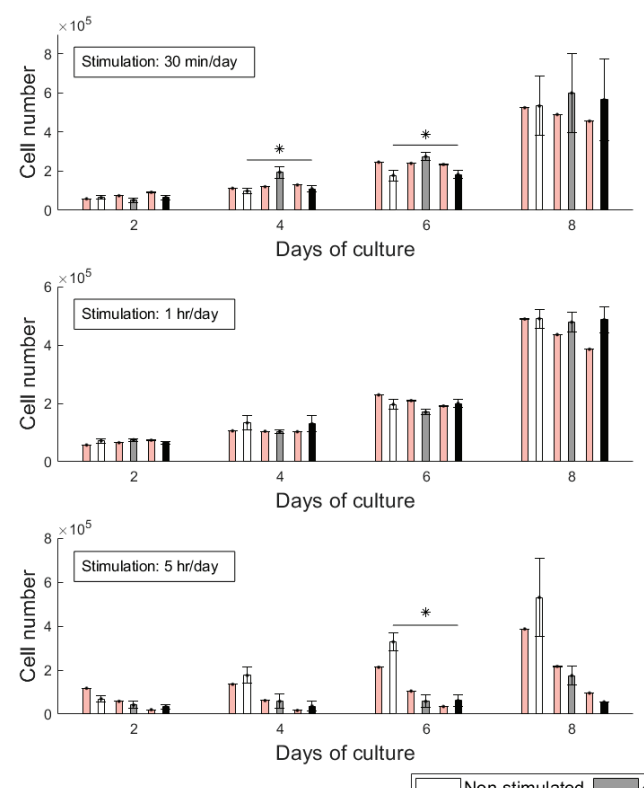

\%
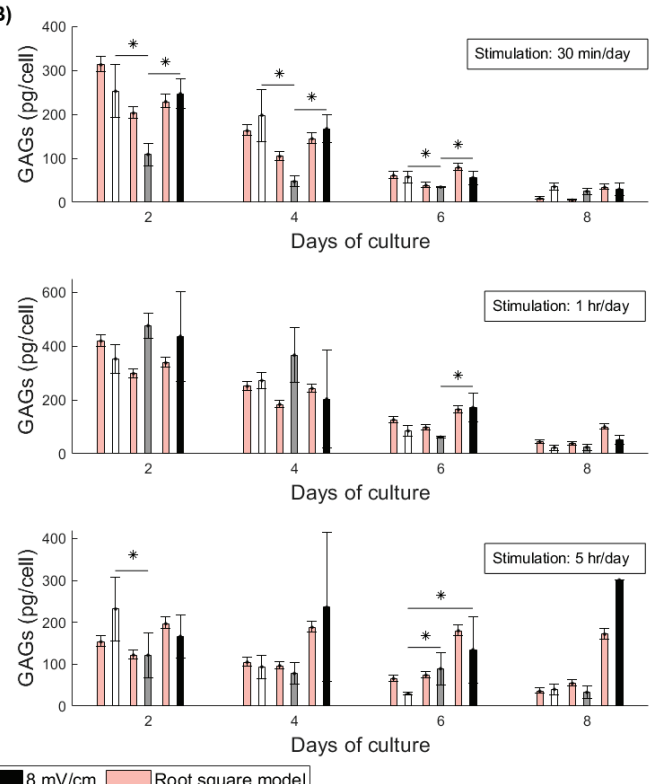

Fig. 10. Representative scheme of cell proliferation and GAGs synthesis of non-stimulated and stimulated cultures with EFs compared to data obtained by the root square model. Predictions (red bars) for each experimental data (grey scale bars) are located on the left side, A) Cell population of chondrocytes, B) GAGs synthesis of chondrocytes. Each scale bar corresponds to the average of three different samples. Experimental data were statistically analyzed, evidencing significant differences between stimulation schemes and controls $(p<0.05 *)$.

The prediction probability of the model was evidenced with error bars, considering a confidence interval of $95 \%$

els that evidenced an $F_{\text {computed }}>F_{\text {rejected }}$ were intended to reject $H_{0}$, concluding that interactive, quadratic and combined terms contribute to the prediction of number of cells/dish and GAGs/cell.

Finally, data were transformed using the root square model and analyzed by using the combined model. Coefficients obtained from the model for both number of cells/dish and content of GAGs/cell are in Eqs. (26) and (27) (Fig. 10). This equation was obtained by eliminating outliers and predictors that do not accomplish levels of significance $p \leq 0.05$. Coefficients $R^{2}$ and $R_{A D J}^{2}$ for number of cells/dish and content of GAGs/cell are in Table 5 .

$$
\begin{gathered}
\sqrt{\mathrm{N} \frac{\text { Cells }}{\text { dish }}}=213.60-16.02 E F \\
-2.31 E F * D_{c}-7.33 E F * T_{s} \\
-7.52 D_{c} * T_{s}+8.42 D_{c}^{2}+6.81 T_{s}^{2},
\end{gathered}
$$




$$
\begin{gathered}
\sqrt{\frac{\mathrm{GAGs}}{\text { cell }}}=19.03-1.68 E F-2.62 D_{c} \\
+7.46 T_{s}+0.114 E F * D_{c}-0.116 E F \\
* T_{s}+0.31 D_{c} * T_{s}+0.135 E F^{2}-1.683 T_{s}^{2} .
\end{gathered}
$$

\section{Discussion}

Several mathematical and computational methods have been implemented for investigating chondrocyte dynamics. On the one hand, the logistic growth model was used by Grote et al. [21] to simulate the dynamic formation of oriented patches in chondrocytes. The Monod model, a mathematical approach that relates population growth rate to the concentration of a limiting resource, was implemented to simulate chondrocytes mitosis cultured in aterocollagen gels [27]. Similarly, the Contois model simulates the inhibition growth caused by cell density, implying saturation of growth due to spatial competition for resources [4]. This model has been implemented to simulate growth kinetics of chondrocytes seeded into polymer matrix [17]. On the other hand, cellular automata have been implemented to simulate chondrocyte dynamics in monolayer [50] and collagen constructs [27], and cells responsible for bone remodelling [51]. Markov chain models have been implemented to simulate, by a perturbational analysis, the role of molecules in the hypertrophic process of chondrocytes [26]. Different models have been implemented to simulate cell behaviour; however, there are not studies that simulate chondrocyte dynamics after stimulation by MFs and EFs. Accordingly, this study is the first attempt that elucidates different equations to predict chondrocyte proliferation and GAGs synthesis when stimulated by MFs and EFs. Each model was analysed to find the best equation that predicts cell population and GAGs synthesis. Therefore, the comparison between $F_{\text {rejected }}$ and $F_{\text {computed }}$ was performed to validate the contribution of $\beta$ terms in the prediction of proliferation and GAGs synthesis. Regarding the equation that models the effect of MFs over expression of GAGs/cell, it was found that the interactive model had an $F_{\text {computed }}=$ 0.48 , smaller than $F_{\text {rejected }}=2.76$. It means that $\beta$ terms do not contribute to prediction of GAGs/cell. Comparing these results with the combined model, the $F_{\text {computed }}=3.04$ was higher than $F_{\text {rejected }}=2.76$, evidencing that $\beta$ terms of combined model contribute to prediction of GAGs/cell. This behavior was not observed for those equations that simulated either prolif- eration or GAGs synthesis stimulated by MFs and EFs; however, the potential prediction of each equation varied according to the model used. In this case, $R^{2}$ were used to provide information about how the dependent variables variation could be explained by the models. The root square model was the equation that better predicted number of cells and GAGs. Regarding the root square model for MFs, it was evidenced that about $92.04 \%$ and $71.06 \%$ of the sample variation in cell population and GAGs synthesis, respectively, can be attributed to using $M F, T_{s}, T_{s}^{2}$ and $D_{c}^{2}$ variables to predict proliferation and GAGs synthesis. Concerning the root square model for EFs, it was evidenced that about $88.19 \%$ and $74.79 \%$ of the sample variation in cell population and GAGs synthesis, respectively, can be attributed to using $E F, E F^{2}$, $T_{s}, T_{s}^{2}, D_{c}$, and $D_{c}^{2}$ variables to predict proliferation and GAGs synthesis. A study by Freed et al. [16] found an equation to simulate chondrocyte proliferation in biodegradable polyglycolic acid scaffolds. Results evidenced that about $99.9 \%$ of the sample variation in cell population can be attributed to using culture time as variable to predict cell density.

Models presented in this study are a combination of interactive and quadratic terms or a combination of both. In equations where interactive terms were considered, $R^{2}$ increased significantly, indicating that the models better predict either number of cells or GAGs synthesis when MFs or EFs are applied. However, not all interactive terms are relevant within the equations to enhance the prediction. For example, in Eq. (10), interaction terms such as $M F * D_{c}(p=0.714)$ and $D_{c} * T_{s}(p=0.465)$ are not statistically significant (data not shown), and can be removed from the equation [32]. Although the terms were not removed, it was possible to observe that all terms contribute to the prediction of proliferation, given that $F_{\text {computed }}=4.36$ was higher than $F_{\text {rejected }}=2.76$. SSER and SSEC parameters may be considered to assess whether the interactive and quadrative terms contribute to the model. In this context, SSEC should be smaller than SSER, and the difference SSER - SSEC - large [32]. For instance, in Table 3, the quadratic model evidenced SSEC $=1.68 E+10$ and SSEC $=7 E+10$ for number of cells and GAGs/cell, respectively. These values were smaller compared to SSER $=2.73 E+10$ for cell population and SSER $=9 E+10$ for GAG concentration. Similar values for SSER and SSEC were found in cultures stimulated with EFs. Considering that models fit these assumptions, it is possible to conclude that equations efficiently predict cell growth and GAGs synthesis when chondrocytes are 
stimulated with MFs and EFs. Nevertheless, a greater range of experimental assays are needed to increase $R^{2}$ and avoid negative values.

Interpretation of $\beta$ coefficients is crucial to understand how these values influence over equations and allow the prediction. For instance, in Eq. (9) the picograms [pg] amount of GAGs expressed by one chondrocyte is given by GAGs/cell $=54.87+5.27 M F$ $-4.56 D_{c}+0.47 T_{s}$. Here, $\beta_{1}=5.27$, indicating that of GAGs/cell increases, the amount of 5.27 times for 1 unit of $M F$ when $D_{c}$ and $T_{s}$ are fixed. A similar interpretation of $\beta_{2}=4.56$ can be expressed, where the amount of GAGs/cell decreases by 4.56 for 1 unit of $D_{c}$ when $M F$ and $T_{s}$ are fixed. Regarding $\beta_{3}=0.47, \mathrm{pg}$ of GAGs/cell will increase 0.47 for 1 unit of $T_{s}$ when the $M F$ and $D_{c}$ are fixed. Finally, $\beta_{0}=54.87$ has into account the pg of GAGs/cell when $\mathrm{M} F, D_{c}$ and $T_{s}$ are zero. This interpretation can be performed for all equations in this study. Even though the main application of this equations lies on the prediction of number of cells and amount of GAGs/cell when chondrocytes are stimulated with MFs and EFs, it is possible to use these models to test the following hypotheses: 1) the mean of the number of pg of GAGs/cell increases as the filed strength increases when $D_{c}$ and $T_{s}$ are constant and 2) the number of cells per dish decreases as stimulation time $T_{s}$ increases when $D_{c}$ and $M F$ are constant. These assumptions need to be confirmed by performing computational simulations to accept or reject the null hypothesis.

Limitations of using a regression analysis could be observed in the linear relationships of dependent and independent variables, as this kind of models assume that there is a straight-line relationship between the variables [32]. This assumption in cell proliferation can be incorrect given that cells in monolayer have two different phases. The Lag phase (from day zero to day fourth) where cells become accustomed to the ambient conditions, and the Log phase (from day fourth to one week) where cells experience an exponential growth [50]. In this study, the reduced and interactive models could not predict efficiently cell proliferation; however, the quadratic, combined and root square models can better predict number of cells due to the exponential variables. Mathematical models can only be used to qualitatively predict cell proliferation, and computational results have limited application for predicting outcomes of alternative therapy regimens with any precision [23]. We observed this behaviour in models where the prediction calculated a negative value. Another limitation using models to predict cell dynamics regards to observational data derived from in vitro experiments, as data is subjected to randomness due to experimental noise and imprecision from measuring devices [23]. Although experimental analyses were performed using the same measuring devices and same reagents, it is relevant to consider these variables to find models that better predict cell behaviour. In fact, equation coefficients vary for cell type, as each cell has a different dynamic depending on the host tissue.

Given that models were fitted using data derived from experimental assays in laboratory, these equations are useful to predict chondrocyte behavior in therapies carried out in the same conditions such as chondrocyte autologous implantation, where cells are grown in vitro to be implanted in the injured cartilage [33]. For equations with a clinical relevance, it is necessary to feedback the models with data obtained clinically [23]. Future perspectives may be focused on developing mathematical models that simulate chondrocyte behaviour in threedimensional environments, where chondrocytes not only maintain its ideal morphology, but also efficiently express the main molecules such as collagen type II, SOX 9 and aggrecan, since these molecules are crucial for cartilage maintenance.

\section{Funding}

Authors gratefully thank the financial support provided by "Fondo Nacional de Financiamiento para la Ciencia, la Tecnología, y la Innovación -Fondo Francisco José de Caldas- Minciencias" and Universidad Nacional de Colombia through the grant No. 80740290-2020.

\section{Conflict of interest}

The authors declare that there is no conflict of interest regarding the publication of this paper.

\section{References}

[1] AkAnji O., Lee D., BADER D., The effects of direct current stimulation on isolated chondrocytes seeded in $3 D$ agarose constructs, Biorheology, 2008. 45 (3-4), 229-243.

[2] Armstrong P., Brighton C., Star A., Capacitively coupled electrical stimulation of bovine growth plate chondrocytes grown in pellet form, J. Orthop. Res., 1988, 6 (2), 265-271.

[3] Baker C., Bocharov G., Paul C., Rihan F., Modelling and analysis of time-lags in some basic patterns of cell proliferation, J. Math. Biol., 1998. 37 (4), 341-371.

[4] Bandeiras C., Completo A., Computational Modelling of Tissue-Engineered Cartilage Constructs, [in:] The Computational Mechanics of Bone Tissue: Biological Behaviour, Remodelling Algorithms and Numerical Applications, J. Belinha, M.-C. Manzanares-Céspedes, A. Completo (Eds.), Springer International Publishing, Cham, Switzerland, 2020, 203-222. 
[5] De Bhowmick G., Sen R., Sarmah A., Analysis of growth and intracellular product synthesis dynamics of a microalga cultivated in wastewater cocktail as medium, Biochem. Eng. J., 2019, 149, 107253.

[6] BRIGHTON C., Townsend P., Increased cAMP production after short-term capacitively coupled stimulation in bovine growth plate chondrocytes, J. Orthop. Res., 1988, 6 (4), 552-558.

[7] Brighton C., Unger A., Stambough J., In vitro growth of bovine articular cartilage chondrocytes in various capacitively coupled electrical fields, J. Orthop. Res., 1984, 2 (1), 15-22.

[8] BRIGHTON C., WANG W., ClARK C., Up-regulation of matrix in bovine articular cartilage explants by electric fields, Biochem. Biophys. Res. Commun., 2006, 342 (2), 556-561.

[9] BRighton C., WANG W., CLARK C., The effect of electrical fields on gene and protein expression in human osteoarthritic cartilage explants, J. Bone Jt. Surg. Am., 2008, 90 (4), 833-848.

[10] Ciombor D., AAROn R., WANG S., SimOn B., Modification of osteoarthritis by pulsed electromagnetic field: a morphological study, Osteoarthr. Cartil., 2003, 11 (6), 455-462.

[11] Elsayed Y., LeKAKou C., TOMLINS P., Modeling, simulations, and optimization of smooth muscle cell tissue engineering for the production of vascular grafts, Biotechnol. Bioeng., 2019, 116 (6), 1509-1522.

[12] Escobar J., Vaca-González J., Guevara J., Vega J., Hata Y., GARZÓN-AlVARAdo D., In Vitro Evaluation of the Effect of Stimulation with Magnetic Fields on Chondrocytes, Bioelectromagnetics, 2019, 41 (1), 41-51.

[13] Fini M., Giavaresi G., Carpi A., Nicolini A., Setti S., GIARDINO R., Effects of pulsed electromagnetic fields on articular hyaline cartilage: Review of experimental and clinical studies, Biomed. Pharmacother., 2005, 59 (7), 388-394.

[14] Fini M., Giavaresi G., Torricelli P., Cavani F., Setti S., CANE V., Giardino R., Pulsed electromagnetic fields reduce knee osteoarthritic lesion progression in the aged Dunkin Hartley guinea pig, J. Orthop. Res., 2005, 23 (4), 899-908.

[15] Fioravanti A., Nerucci F., Collodel G., Markoll R., MARCOLONGO R., Biochemical and morphological study of human articular chondrocytes cultivated in the presence of pulsed signal therapy, Ann. Rheum. Dis., 2002, 61 (11), 1032-1033.

[16] Freed L., Marquis J., Langer R., Vunjak-Novakovic G., Kinetics of chondrocyte growth in cell-polymer implants, Biotechnol. Bioeng., 1994, 43 (7), 597-604.

[17] Galban C., Locke B., Analysis of cell growth kinetics and substrate diffusion in a polymer scaffold, Biotechnol. Bioeng., 1999, 65 (2), 121-132.

[18] Garijo N., Manzano R., Osta R., Perez M.A., Stochastic cellular automata model of cell migration, proliferation and differentiation: Validation with in vitro cultures of muscle satellite cells, J. Theor. Biol., 2012, 314, 1-9.

[19] GonZÁlez-VAlverde I., GarcíA-AZnar J., An agent-based and FE approach to simulate cell jamming and collective motion in epithelial layers, Comput. Part. Mech., 2019, 6 (1), 85-96.

[20] Goudar C., Joeris K., Konstantinov K., Piret J., Logistic Equations Effectively Model Mammalian Cell Batch and FedBatch Kinetics by Logically Constraining the Fit, Biotechnol. Prog., 2005, 21 (4), 1109-1118.

[21] Grote M., Palumberi V., Wagner B., Barbero A., Martin I., Dynamic formation of oriented patches in chondrocyte cell cultures, J. Math. Biol., 2011, 63 (4), 757-777.

[22] Jahns M., Lou E., Durdle N., Bagnall K., Raso V., Cinats D., BARley R., Cinats J., JOMHa N., The effect of pulsed electromagnetic fields on chondrocyte morphology, Med. Biol. Eng. Comput., 2007, 45 (10), 917-925.
[23] Jarrett A., Lima E., Hormuth D., McKenna M., Feng X., Ekrut D., Resende A., Brock A., YANKeelov T., Mathematical models of tumor cell proliferation: A review of the literature, Expert Rev. Anticancer Ther., 2018, 18 (12), $1271-1286$.

[24] JiN W., McCue S., Simpson M., Extended logistic growth model for heterogeneous populations, J. Theor. Biol., 2018, 445, 51-61.

[25] Jin W., Penington C., McCue S., Simpson M., Stochastic simulation tools and continuum models for describing twodimensional collective cell spreading with universal growth functions, Phys. Biol., 2016, 13 (5), 56003.

[26] Kerkhofs J., Leijten J., Bolander J., Luyten F., Post J., GERIS L., A Qualitative Model of the Differentiation Network in Chondrocyte Maturation: A Holistic View of Chondrocyte Hypertrophy, PLoS One, 2016, 11 (8), 1-27.

[27] Kino-OKa M., Maeda Y., Yamamoto T., Sugawara K., TAYA M., A kinetic modeling of chondrocyte culture for manufacture of tissue-engineered cartilage, J. Biosci. Bioeng., 2005, 99 (3), 197-207.

[28] VAN LIEDEKERKE P., Quantitative modeling of cell and tissue mechanics withagent-based models, Inria Paris, Sorbonne Université, 2019.

[29] De Mattei M., Caruso A., Pezzetti F., Pellati A., Stabellini G., Sollazzo V., Traina G., Effects of pulsed electromagnetic fields on human articular chondrocyte proliferation, Connect Tissue Res., 2001, 42 (4), 269-279.

[30] De Mattei M., Pasello M., Pellati A., Stabellini G., Massari L., Gemmati D., Caruso A., Effects of electromagnetic fields on proteoglycan metabolism of bovine articular cartilage explants, Connect Tissue Res., 2003, 44 (3-4), 154-159.

[31] De Mattei M., Pellati A., Pasello M., Ongaro A., Setti S., Massari L., Gemmati D., Caruso A., Effects of physical stimulation with electromagnetic field and insulin growth factor-I treatment on proteoglycan synthesis of bovine articular cartilage, Osteoarthr. Cartil., 2004, 12 (10), 793-800.

[32] Mendenhall W., Sincich T., Principles of Model Building. In $A$ second course in statistics regression analysis, Prentice Hall, Boston, MA, 2012, 261-325.

[33] Minas T., Ogura T., Bryant T., Autologous Chondrocyte Implantation, JBJS Essent. Surg. Tech., 2016, 6 (2), 1-11.

[34] Nicolakis P., Kollmitzer J., Crevenna R., Bittner C., Erdogmus C., Nicolakis J., Pulsed magnetic field therapy for osteoarthritis of the knee: a double-blind sham-controlled trial, Wien Klin. Wochenschr., 2002, 114 (15-16), 678-684.

[35] Nicolin V., Ponti C., Baldini G., Gibellini D., Bortul R., ZWeyer M., MARTinelli B., NARDUCCI P., In vitro exposure of human chondrocytes to pulsed electromagnetic fields, Eur. J. Histochem., 2007, 51 (3), 203-212.

[36] Omar R., Abdullah M., Hasan M., Rosfarizan M., MARZIAH M., Kinetics and modelling of cell growth and substrate uptake inCentella asiatica cell culture, Biotechnol. Bioprocess Eng., 2006, 11 (3), 223-229.

[37] Ongaro A., Pellati A., Masieri F., Caruso A., Setti S., CAdossi R., Biscione R., Massari L., Fini M., De Mattei M., Chondroprotective effects of pulsed electromagnetic fields on human cartilage explants, Bioelectromagnetics, 2011, 32 (7), 543-551.

[38] Persson S., Wei H., Milne J., Page G., Somerville C., Identification of genes required for cellulose synthesis by regression analysis of public microarray data sets, Proc. Natl. Acad. Sci. U.S.A., 2005, 102 (24), 8633-8638. 
[39] PiPItone N., ScotT D., Magnetic pulse treatment for knee osteoarthritis: a randomised, double-blind, placebo-controlled study, Curr. Med. Res. Opin., 2001, 17 (3), 190-196.

[40] Rodan G., Bourret L., Norton L., DNA synthesis in cartilage cells is stimulated by oscillating electric fields, Science (80-.). 1978, 199 (4329), 690-692.

[41] Sartori R., Leme J., Caricati C., Tonso A., NúÑez E., Model comparison to describe bhk-21 cell growth and metabolism in stirred tank bioreactors operated in batch mode, Brazilian Journal of Chemical Engineering, 35, 441-458.

[42] Schmidt-Rohlfing B., Silny J., Woodruff S., Gavenis K., Effects of pulsed and sinusoid electromagnetic fields on human chondrocytes cultivated in a collagen matrix, Rheumatol. Int., 2008, 28 (10), 971-977.

[43] Sherley J., Stadler P., Stadler J., A quantitative method for the analysis of mammalian cell proliferation in culture in terms of dividing and non-dividing cells, Cell Prolif., 1995, 28 (3), 137-144.

[44] Shirsat N., Mohd A., Whelan J., English N., Glennon B., Al-RubeAi M., Revisiting Verhulst and Monod models: analysis of batch and fed-batch cultures. Cytotechnology, 2015, 67 (3), 515-530.

[45] Szasz N., Hung H., Sen S., Grodzinsky A., Electric field regulation of chondrocyte biosynthesis in agarose gel constructs, [in:] 49th Annual Meeting of the Orthopaedic Research Society, Orthopaedic Research Society, New Orleans, LA, 2003, 1.

[46] Trock D., Bollet A., Dyer Jr. R., Fielding L., Miner W., MARKoll R., A double-blind trial of the clinical effects of pulsed electromagnetic fields in osteoarthritis, J. Rheumatol., 1993, 20 (3), 456-460.
[47] Trock D., Bollet A., Markoll R., The effect of pulsed electromagnetic fields in the treatment of osteoarthritis of the knee and cervical spine. Report of randomized, double blind, placebo controlled trials, J. Rheumatol., 1994, 21 (10), 1903-1911.

[48] Vaca-González J., Guevara J., Moncayo M., Castro-Abril H., Hata Y., Garzón-Alvarado D., Biophysical stimuli: a review of electrical and mechanical stimulation in hyaline cartilage, Cartilage, 2019, 10 (2), 157-172.

[49] Vaca-González J., Guevara J., Vega J., GarzóN-Alvarado D., An In Vitro Chondrocyte Electrical Stimulation Framework: A Methodology to Calculate Electric Fields and Modulate Proliferation, Cell Death and Glycosaminoglycan Synthesis, Cell. Mol. Bioeng., 2016, 9 (1), 116-126.

[50] Vaca-GonzÁlez J., Gutiérrez M., Guevara J., GarzóN-Alvarado D., Cellular automata model for human articular chondrocytes migration, proliferation and cell death: An in vitro validation, In: Silico Biol., 2017, 12 (3-4), 83-93.

[51] Velasquez A., Behavioral model of a basic trabecular-bone multi-cellular unit using cellular automaton, Visión Electrónica, 2014. 8 (1), 6-18.

[52] Wang W., Wang Z., Zhang G., Clark C., Brighton C., Up-regulation of chondrocyte matrix genes and products by electric fields, Clin. Orthop. Relat. Res., 2004, 427, 163-173.

[53] Warne D., BAKer R., Simpson M., Optimal Quantification of Contact Inhibition in Cell Populations, Biophys. J., 2017, 113 (9), 1920-1924.

[54] XU P., Analytical solution for a hybrid Logistic-Monod cell growth model in batch and continuous stirred tank reactor culture, Biotechnol. Bioeng., 2020, 117 (3), 873-878. 